\title{
Implementasi SCRUM dalam Perancangan Aplikasi Emergency Button PMI Kota Malang
}

\author{
Lia Farokhah ${ }^{1}$, Fadhli Almu'iini Ahda ${ }^{2}$, Lukman Hakim ${ }^{3}$ \\ 1,2,3 Institut Teknologi dan Bisnis ASIA Malang \\ ${ }^{1,2,3}$ rogram Studi Teknik Informatika Fakultas Teknologi dan Desain, \\ Institut Teknologi dan Bisnis ASIA)
}

Jl. Soekarno Hatta-Rembuksari 1A, Malang, Jawa Timur, telp. 0341478877

e-mail: ${ }^{1}$ farokhah@asia.ac.id, ${ }^{2}$ fadhlial@asia.ac.id, ${ }^{3}$ bledek.lukman@asia.ac.id

\begin{abstract}
Abstrak
Palang Merah Indonesia (PMI) Malang merupakan salah satu organisasi kemasyarakatan yang bergerak dalam bidang sosial kemanusiaan. PMI membutuhkan media komunikasi yang efektif kepada masyarakat. PMI bertugas menanggulangi kecelakaan, kedaruratan medis dan mengevakuasi korban. PMI memiliki beberapa kendala dalam menjalankan tugasnya yaitu kurangnya peran serta pelapor atau masyarakat dalam melaporkan kejadian. PMI menerima laporan kejadian melalui media sosial atau komunitas sehingga penanganannya kurang cepat dan tanggap. Perancangan Aplikasi emergency button dirancang untuk memenuhi kebutuhan para stakeholder yaitu PMI dan masyarakat. Pengembangan rancangan sistem menggunakan metode SCRUM. Metode ini membuat timeline pekerjaan menjadi lebih tertata dan detail Penelitian ini mengukur tingkat prioritas produk backlogs. Prioritas produk backlog admin PMI, driver dan masyarakat atau pelapor cukup tinggi dengan prosentase sekitar 70-100\%. Adapun satu fasilitas pelapor memiliki prioritas terendah sekitar 44\% tentang pemberian feedback kepada PMI tentang kecepatan layanan yang diberikan kepada pelapor. Hasil prioritas produk backlogs akan memudahkan stakeholder pada SCRUM untuk melanjutkan proses penetapan rencana sprint.
\end{abstract}

Kata kunci: Kecelakaan, Darurat, Medis, PMI, SCRUM

\begin{abstract}
Palang Merah Indonesia (PMI) Malang is one of the social organizations engaged in social humanity. PMI requires effective communication media to the public. PMI has a duty to deal with accidents, medical emergencies and evacuate victims to health facilities. PMI has several obstacles in carrying out of their duties, namely the lack participation of the society. PMI receives incident reports through social media so that the handling is less fast and responsive. Emergency button application is designed to meet the needs of the stakeholders namely PMI and the community. Development of system design using SCRUM. This method makes the work timeline more organized and detailed. This research measures the priority level of backlog products. The backlog product priority of PMI administrator, driver and society are quite high with a percentage of around 70-100\%. One report facility has the lowest priority of about $44 \%$ regarding providing feedback to PMI about the speed of service provided to the society. The priority results of the backlog product will make it easier for stakeholders at SCRUM to continue the process of determining the sprint plan.
\end{abstract}

Keywords: Accident, Emergency, Medical, PMI, SCRUM 


\section{Pendahuluan}

Kecelakaan di Indonesia memiliki kecenderungan meningkat dari tahun ketahun. Adapun jumlah korban yang teridentifikasi dari kantor kepolisian republik Indonesia yang tercatat di badan pusat statistik dari tahun 1992-2017 yang meliputi jumlah kecelakaan, korban meninggal, luka berat dan luka ringan memiliki kecenderungan meningkat [1]. Kota malang dalam 3 tahun berturut-turut dari tahun 2014-2016, data statistik menunjukkan bahwa kejadian kecelakaan yang mengakibatkan meninggal dunia dan luka cenderung naik. Statistik yang ada hanya menunjukkan kasus yang dilaporkan. Dalam sebuah kecelakaan atau kejadian bencana, pasti terdapat korban yang terlibat. Penanganan korban pasca kejadian merupakan salah satu aspek penting dalam mengurangi jumlah korban dan efek yang lebih buruk. Salah satu organisasi yang ada di Indonesia yang menangani hal tersebut adalah Palang Merah Indonesia(PMI). PMI merupakan organisasi kemasyarakatan yang melaksanakan kegiatan bidang sosial kemanusiaan yang melibatkan partisipasi masyarakat/relawan sebagai kekuatan organisasi. PMI memiliki tugas menanggulangi penderita kecelakaan dan kedaruratan medis, serta mampu membantu mengevakuasi korban ke fasilitas kesehatan yang ada[2]. Salah satu bidang yang ditangani PMI adalah penyediaan ambulance. Jenis layanan terdiri dari dua jenis yaitu ambulance emergency yang terdiri dari layanan respon laka lantas, operasi bencana, rujukan dan event. Jenis ambulance jenazah yang terdiri dari pemakaman dan evakuasi.

Dalam penanganan korban, PMI memiliki beberapa kendala dan pengalaman dalam lapangan seperti berita kecelakaan yang tidak dilaporkan secara cepat ke pihak yang memiliki kemampuan dalam penanganan tetapi muncul dan mendeteksi korban dari sosial media, organisasi masyarakat (Ormas), organisasi amatir radio Indonesia (Orari), kepolisian. Informasi dari masyarakat yang cenderung merupakan stakeholder pertama yang melihat kejadian sangatlah minim. Masyarakat tidak memiliki media yang tepat dan informasi yang tersosialisasi dengan baik sehingga peran masyarakat sangat kecil dalam pelaporan. Selama ini, pelaporan tercepat bisa ditempuh dengan menghubungi nomor kantor PMI. Pelaporan dengan media telepon kantor sangatlah tidak praktis dan diabaikan karena pada era sekarang orang lebih banyak menggunakan media smartphone berkuota internet. Hal ini merupakan salah satu hal yang mengkhawatirkan karena termasuk hal yang memiliki urgensi untuk perubahan proses bisnis pertolongan emergency.

Dewasa ini banyak berdiri organisasi sosial yang turut berpartisipasi dalam penyelenggaraan pelayanan ambulance, tetapi ada yang melupakan tentang kualitas dimana ambulance hanya sebagai alat transportasi saja. PMI memiliki kualitas yang dijaga dengan baik dengan beberapa kelebihan yang sangat memadai misalkan PMI memiliki kerjasama terhadap asosiasi rumah sakit dan ada aturan yang kuat dimana rumah sakit tidak bisa menolak korban yang ada, kepolisian, Badan penanggulangan bencana daerah (BPBD), jasa raharja, lembaga terkait penanganan korban yang tidak memiliki keluarga atau gelandangan dimana sudah terkoneksi dengan dinas sosial. PMI juga memiliki sebuah roadmap rumah sakit rujukan sesuai dengan kasus yang ada misalkan kecelakaan dengan luka tertentu di rujuk ke rumah sakit yang memang sudah memiliki kemampuan penanganan tersebut sehingga tidak salah dalam tindakan pasca kecelakaan dan bisa meminimalkan korban jiwa meninggal dunia.

PMI membutuhkan alat komunikasi antara masyarakat atau pelapor, korban, lembaga terkait dalam sosialisasi dan penanganan pasca kejadian yang tersistem dan komprehensif sehingga bisa mengurangi efek yang buruk. Adapun kejadian yang baru-baru ini viral di dunia maya tahun 2019 adalah ada seorang bapak yang menggendong mayat anaknya karena tidak difasilitasi ambulance oleh puskesmas dan kurangnya pengetahuan dengan organisasi terkait dalam penyediaan ambulance. PMI kota malang memiliki armada yang cukup dalam penanganan korban yang ada dengan fasilitas yang berkualitas serta penanganan dalam 
perjalanan ke fasilitas kesehatan. Dalam aplikasi yang dirancang, bisa melibatkan ambulance yang tersedia dari organisasi sosial yang ada dengan bantuan pengarahan PMI yang memiliki roadmap fasilitas yang sudah jelas. Namun, dalam aplikasi ini akan memaksimalkan peran PMI sebagai stakeholder inti.

Sistem ini akan menangani beberapa fasilitas utama seperti pelaporan kejadian, estimasi waktu tiba, fasilitas kesehatan rujukan sesuai kasus, tracking jalan yang bisa dipantau dari admin PMI untuk mobil ambulance, cctv dalam ambulance dimana infomasi tentang kondisi korban saat perjalanan bisa dilakukan pertolongan pertama oleh dokter yang stand by di PMI karena permasalahan yang ada dilapangan adalah kesulitan penyediaan dokter yang ada dalam ambulance sehingga bisa diterapkan seperti sistem yang ada di singapura yaitu penyediaan informasi di dalam ambulance untuk dokter yang tersedia di lokasi PMI/ rekanan. Disisi lain, kota malang yang hanya terdiri dari 5 kecamatan memiliki fasilitas kesehatan yang sangat memadai dan tersebar dengan baik di kota malang sehingga fasilitas ini merupakan fasilitas tambahan. Aplikasi ini nantinya juga membantu kejadian kecelakaan di wilayah lain dimana ketika memakai aplikasi emergency button jika diluar kota malang aka nada informasi tentang pmi di wilayah tersebut sehingga PMI kota malang akan dijadikan percontohan dimana diharapkan setelah ini dikembangkan bisa terhubung diseluruh wilayah di seluruh Indonesia dengan melihat manfaat kemanusiaan dan penanganan yang ditawarkan untuk mengurangi efek yang lebih buruk dengan sistem yang komprehenshif.

Metode yang digunakan dalam pengembangan sistem adalah metode SCRUM. Metode ini sudah dipakai dalam berbagai kebutuhan projek [3] [4] [5] [6]maupun diadaptasi untuk non projek [7]. Penelitian sebelumnya berfokus pada setiap langkah pada metode SCRUM dalam projek. Penelitian ini mengadopsi penelitian legislation information system dengan berfokus penentuan prioritas produk backlog yang akan dikembangkan[4]. Perbedaan yang ditonjolkan adalah mempertajam komunikasi pembuatan produk backlogs dengan stakeholder terkait melalui sebuah forum group discussion dalam perancangan desain produk backlogs. Forum group discussion memiliki keunggulan dalam hal komunikasi langsung, penghematan waktu dibandingkan mewawancarai perorangan stakeholder serta pengumpulan data yang lebih cepat karena mengumpulkan semua pihak yang terlibat. Dalam pembuatan sebuah aplikasi, desain aplikasi yang dibuat menjadi salah hal terpenting aplikasi ini bisa dipakai secara maksimal jika memenuhi kebutuhan stakeholder yang akan memakai sistem yang sedang dikembangkan. Selain itu, pada metode SCRUM penentuan produk backlogs mempengaruhi langkah siklus metode SCRUM selanjutnya. Adapun beberapa keunggulan SCRUM yaitu meningkatnya publikasi tentang metode ini [8], lebih cepat dan efisien[9], banyak dipakai di industri pernagkat lunak karena praktis[10], menguatkan perencanaan dan kerjasama yang baik[11], berorientasi pada kualitas[11]. Scrum dikenal sebagai proses perangkat lunak yang signifikan yang membedakannya dari pendekatan Agile lain seperti XP, proses terpadu Agile[12].

\section{Metode Penelitian}

\subsection{Desain Penelitian}

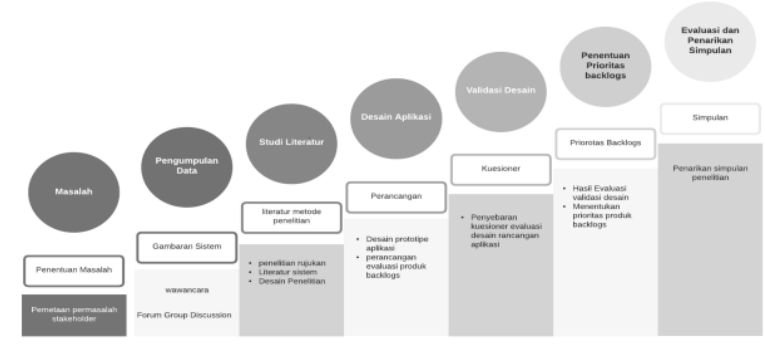

Gambar 1. Desain Penelitian 
Adapun desain penelitian yang diusulkan ditunjukkan pada Gambar 1. Desain penelitian dimulai dengan definisi dan penggalian masalah yang ada, pengumpulan data, studi literatur kemudian dilanjutkan dengan mendesain rancangan aplikasi. Setelah rancangan prototipe, dibuat metode evaluasi desain, evaluasi hasil prioritas backlogs kemudian mengambil kesimpulan dari hasil yang didapatkan.

\subsection{Metode Penelitian}

Adapun metode penelitian yang dibuat sebagai berikut:

1. Literatur Studi,

Mencari literatur melalui dokumen seperti buku laporan PMI kota Malang dan beberapa laporan penelitian terkait.

2. Penelitian Lapangan

Penelitian lapangan dilakukan dengan dua acara yaitu observasi dan wawancara. Observasi lapangan dan wawancara dilakukan pada pihak PMI dan Mitra PMI terkait informasi yang dibutuhkan.

3. Pengumpulan kebutuhan sistem dengan kuesioner, forum group discussion

Dalam pengumpulan data untuk perancangan aplikasi dilakukan dengan wawancara, kuesioner, dan group discussion. Dalam pengujian tingkat kepentingan prioritas dilakukan dengan cara kuesioner menggunakan metode offline dan online disesuaikan objek yang akan diberikan pertanyaan. Adapun demografi responden digambarkan pada Tabel 1.

Tabel 1. Demografi Responden

\begin{tabular}{|c|l|c|}
\hline No & \multicolumn{1}{|c|}{ Objek } & Jumlah \\
\hline $\mathbf{1}$ & Tim PMI (Admin, Driver dan pemangku kebijakan) & 25 \\
\hline $\mathbf{2}$ & Masyarakat (pelapor, organisasi masyarakat, mitra informasi) & 25 \\
\hline
\end{tabular}

4. Sistem Analisis Desain Sistem

Analisis desain sistem dimulai dari analisis dokumen PMI, standart operation procedure (SOP), forum group discussion. Kemudian dilakukan pengujian desain fasilitas sistem yang dirancang melalui sebuah kuesioner menggunakan skala likert[13].

5. Metode Pengembangan Sistem

Metode pengembangan sistem menggunakan metode SCRUM

\subsection{Metode Pengembangan Sistem Menggunakan SCRUM}

SCRUM adalah salah satu framework yang bersifat agile untuk pengembangan perangkat lunak yang adaptif dan menghasilkan perangkat lunak sesuai kebutuhan pengguna [14]. SCRUM memiliki 3 konsep yaitu agile, incremental dan iterative[4]. Metode SCRUM memiliki tiga stakeholder penting yaitu product owner, scrum master dan tim pengembangan[5]. Secara umum proses SCRUM ditunjukkan pada Gambar 2 [12].

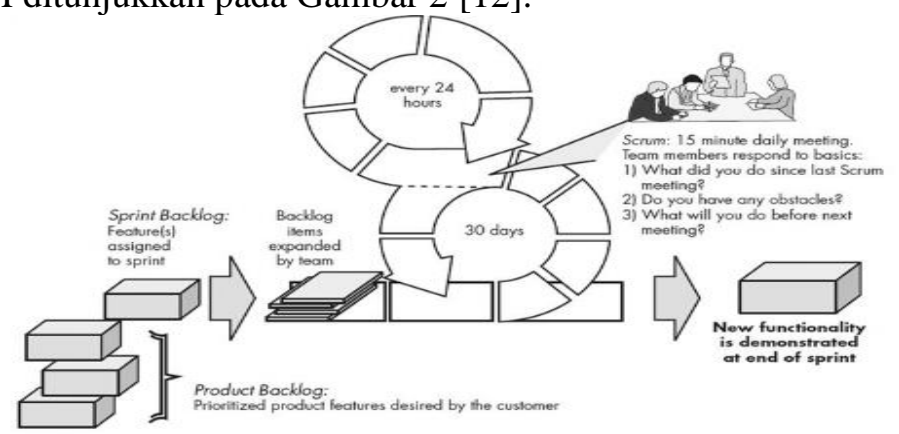

Gambar 2. Gambaran Metode SCRUM[12] 
Adapun penjelasan proses scrum secara umum dari gambar 3 adalah sebagai berikut:

1. backlogs - daftar persyaratan fungsional dalam skala preferensi, yang dapat berubah selama pengembangan;

2. Sprints - unit kerja yang dibutuhkan untuk mencapai persyaratan backlog dalam jaminan dengan kerangka waktu (biasanya 30 hari);

3. Rapat scrum - pendek (biasanya 15 menit) pertemuan di antara anggota tim yang melibatkan master Scrum mengoordinasikan tim dan fokus pada menjawab tiga pertanyaan "apa kendala yang dihadapi? dan apa yang Anda rencanakan pertemuan berikutnya?

4. Demo - peningkatan perangkat lunak dikirim ke pelanggan untuk evaluasi, yang meliputi fungsi yang diminta untuk disampaikan dalam kotak waktu yang ditetapkan

Adapun tahap Metode SCRUM Secara Detail adalah sebagai berikut[3]:

1. Penetapan Product Backlog

Product Backlog merupakan inti dari kerangka Scrum dimana proses Scrum dimulai.

Product Backlog berisi daftar urutan segala sesuatu yang dibutuhkan dalam pengembangan perangkat lunak atau persyaratan yang ditentukan untuk perubahan perangkat lunak. Pada tahap ini product owner akan berurusan dengan perwakilan stakeholder terkait dengan bantuan scrum master melalui forum group discussion PMI dalam merancang product backlog. Setelah perancangan produk backlog, scrum master akan merancang kuesioner untuk penentuan prioritas product backlog yang akan dikembangkan. Kuesioner dibagikan kepada stakeholder terkait dengan jumlah sampel yang lebih banyak sehingga rancangan aplikasi ini bisa teruji manfaat dan desainnya.

2. Penetapan Rencana Sprint

Sprint merupakan iterasi atau siklus dalam satuan waktu terkait rencana tasks yang akan dikerjakan. Tiap tasks yang diselesaikan di setiap sprint harus menciptakan sesuatu dari nilai nyata kepada pelanggan atau pengguna. Di dalam tiap Sprint harus didefinisikan secara jelas manajemen waktu projek. Selain itu, juga ditetapkan urutan prioritas tiap tasks yang dikembangkan, jumlah pengembang yang terlibat serta bagaiman langkahlangkah dalam penyelesaian tiap tasks.

3. Eksekusi Sprint

Eksekusi sprint dapat dianalogikan dengan pengerjaan potongan bagian pengembangan sistem oleh tim Scrum untuk memenuhi tujuan tiap sprint. Sprint dikatakan selesai jika memenuhi tingkat kepercayaan yang tinggi dari pengguuna bahwa semua pekerjaan yang diperlukan untuk menghasilkan fitur berkualitas baik telah selesai.

5. Rencana Scrum Harian

Merupakan aktivitas harian yang dilakukan oleh tim Scrum untuk memeriksa dan menyesuaikan tiap tasks dalam sprint dengan kebutuhan pengguna

Beberapa penelitian yang berhasil menerapkan metode SCRUM dan menghasilkan hasil yang makismal baik dibidang perancangan sistem [15] [6] atau adopsi SCRUM untuk non perancangan[7].

\subsection{ERD Sistem}

Entity relationship diagram (ERD) merupakan pemodelan awal basis data [16]. ERD dikembangkan berdasarkan teori himpunan dalam bidang matematika. Adapun entity relationship diagram sistem terdiri dari 3 stakeholder yaitu admin, driver dan pelapor atau masyarakat. Gambaran dari ERD dari system yang dirancang ditunjukkan pada Gambar 3. 


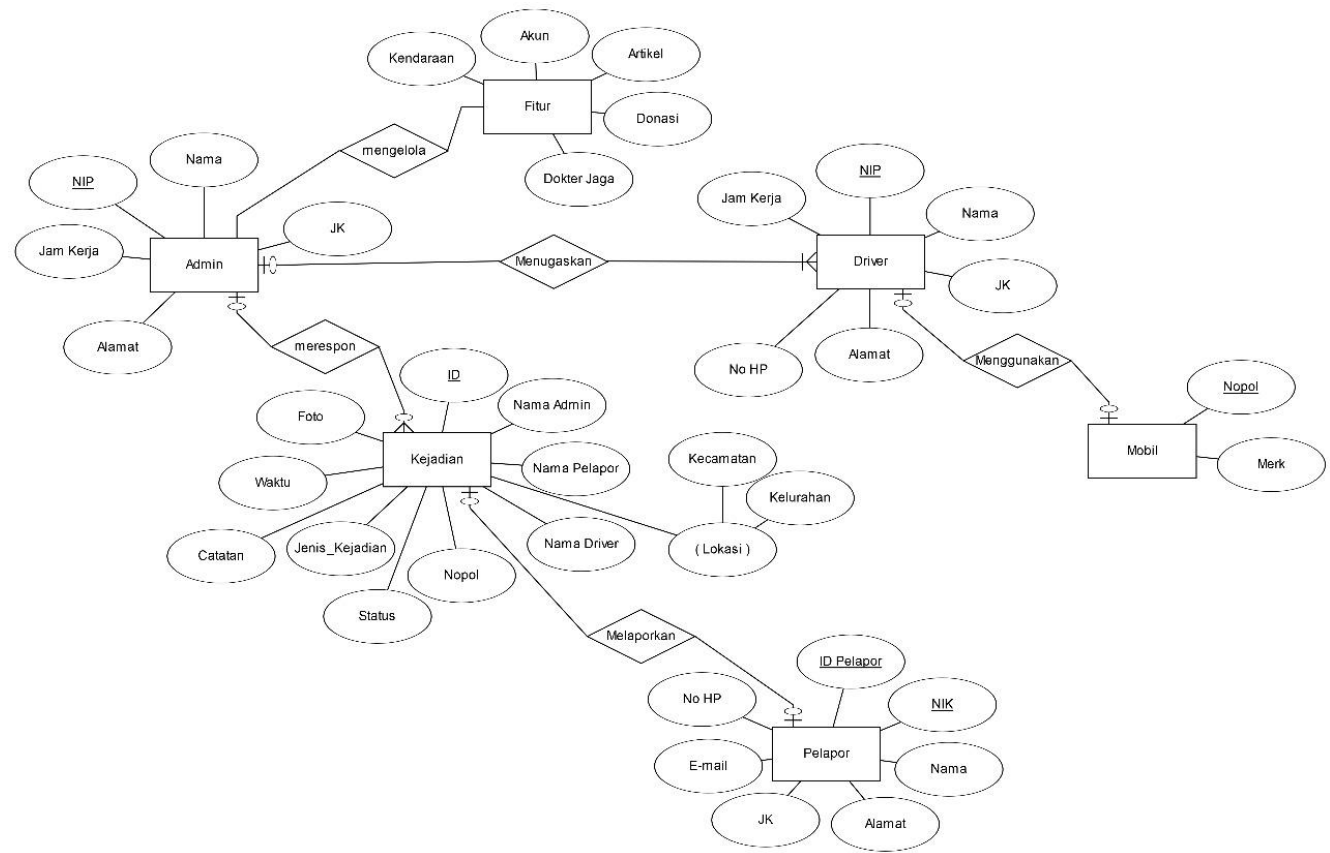

Gambar 3. ERD Sistem Emergency Button PMI

\subsection{Rancangan Sistem}

Adapun rancangan antarmuka sistem aplikasi ditunjukkan pada Gambar 4 - Gambar 7.

1. User

a. Menu Login (Android)

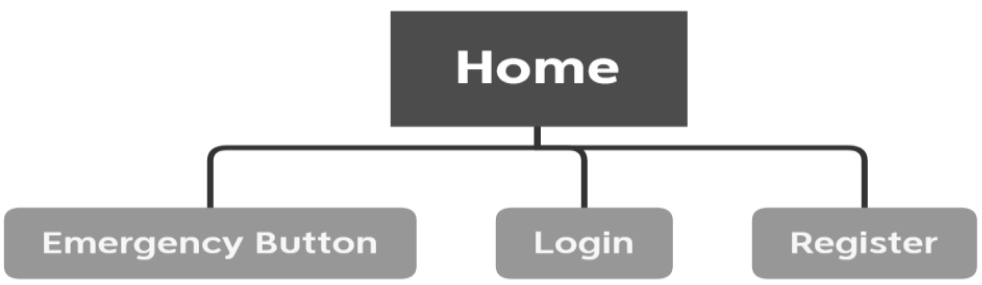

Gambar 4. Antarmuka login sistem

b. Menu Masyarakat (Android)

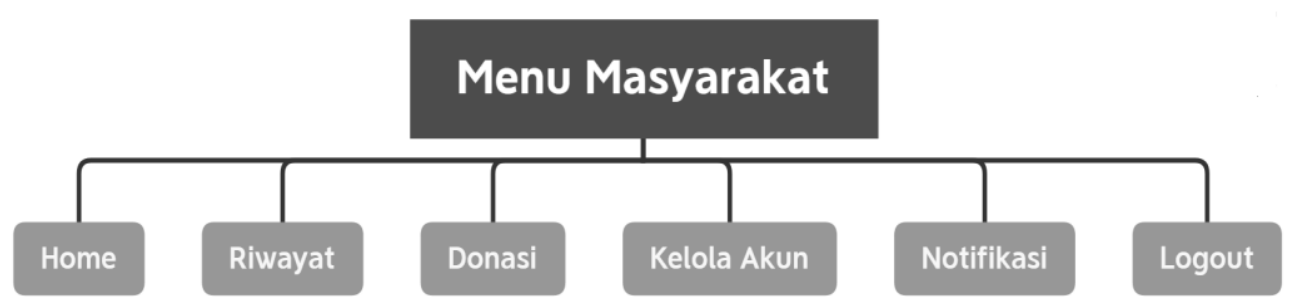

Gambar 5. Antarmuka Masyarakat 
2. Admin

a. Menu Dashboard (Desktop)

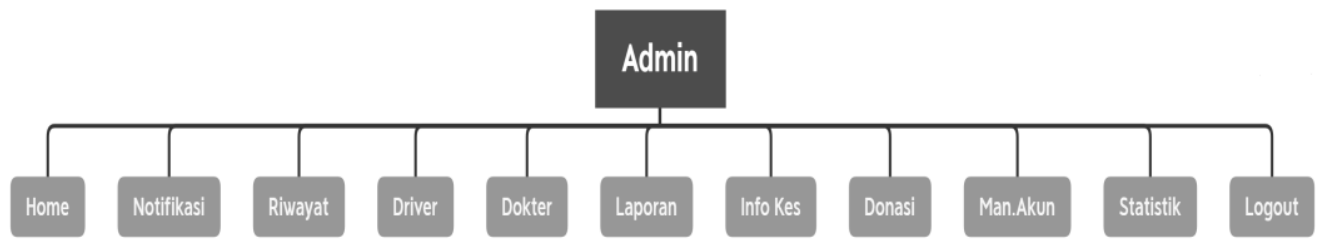

Gambar 6. Antarmuka Admin PMI

3. Driver

a. Menu Dashboard Driver (Android)

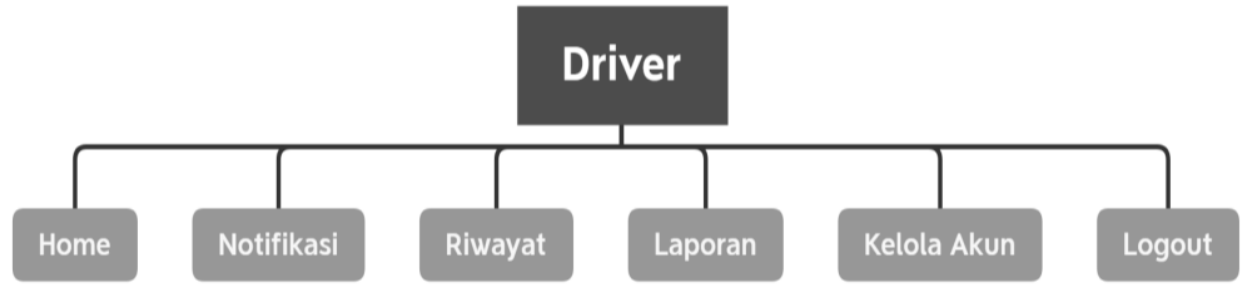

Gambar 7. Antarmuka driver

\section{Hasil dan Pembahasan}

\subsection{Produk Backlog}

Adapun product backlog yang dihasilkan dikelompokkan menjadi tiga yaitu untuk admin PMI sebagai aktor utama pemantau kasus, driver PMI sebagai pelaksana lapangan, dan masyarakat sebagai pelapor kejadian. Produk backlog untuk admin PMI digambarkan pada Tabel 2 sedangkan produk backlog untuk driver PMI digambarkan pada Tabel 3 dan masyarakat atau pelapor digambarkan pada Tabel 4.

Tabel 2. Produk Backlog Admin PMI

\begin{tabular}{|l|l|}
\hline No & Product Backlog admin PMI \\
\hline 1 & $\begin{array}{l}\text { Melihat Progress Monitor Kejadian Emergency atau non } \\
\text { Emergency yang sedang ditangani PMI pada layar utama } \\
\text { antarmuka admin }\end{array}$ \\
\hline 2 & $\begin{array}{l}\text { Melihat data statistika kejadian emergency atau non emergency } \\
\text { yang ditangani PMI selama satu tahun berlangsung }\end{array}$ \\
\hline 3 & Memberikan informasi tambahan tentang kesehatan \\
\hline 4 & Melaporkan transparansi donasi dari masyarakat ke PMI \\
\hline 5 & $\begin{array}{l}\text { Memberikan Rumah sakit rujukan terbaik kepada driver (roadmap } \\
\text { rumah sakit) }\end{array}$ \\
\hline 6 & $\begin{array}{l}\text { Admin PMI bisa memantau keberadaan Driver melalui GPS dari } \\
\text { berangkat sampai kembali ke PMI }\end{array}$ \\
\hline 7 & Laporan Kejadian secara lengkap dan terklarifikasi dengan jelas \\
\hline 8 & $\begin{array}{l}\text { Laporan statistik waktu rata-rata yang dibutuhkan dalam } \\
\text { penanganan setiap kejadian }\end{array}$ \\
\hline
\end{tabular}


Tabel 3. Produk Backlog Driver

\begin{tabular}{|l|l|}
\hline No & Product Backlog Driver \\
\hline 1 & $\begin{array}{l}\text { Melihat tugas yang sedang diberikan secara langsung } \\
\text { Misal: bisa melihat jalur lokasi dari lokasi asal, roadmap rumah } \\
\text { sakit rujukan sesuai kasus lapangan }\end{array}$ \\
\hline 2 & $\begin{array}{l}\text { Memberikan status tugas yang sedang berlangsung sehingga bisa } \\
\text { dipantau oleh admin PMI }\end{array}$ \\
\hline 3 & Membuat berita acara kejadian dan penanganan lapangan \\
\hline
\end{tabular}

Tabel 4 Produk Backlog Pelapor

\begin{tabular}{|l|l|}
\hline No & Product Backlog Pelapor \\
\hline 1 & $\begin{array}{l}\text { Melaporkan kejadian secara cepat melalui emergency button tanpa } \\
\text { dibingungkan dengan administrasi form secara detail sehingga bias } \\
\text { melaporkan kejadian secara cepat }\end{array}$ \\
\hline 2 & Melihat status kejadian yang dilaporkan sampai selesai \\
\hline 3 & Publikasi berita kejadian disitus PMI \\
\hline 4 & Memberikan pesan dan kesan layanan tanggap PMI \\
\hline
\end{tabular}

Dalam pengembangan aplikasi emergency button ditentukan prioritas produk backlog dengan cara menerima umpan balik melalui kuesioner. Kuesioner yang disebar ada 3 yaitu untuk tim PMI, khusus driver dan masyarakat. Setiap stakeholder memberikan masukan prioritas atau tingkat kepentingan setiap produk backlog. Dari hasil kuesioner yang disebar diberikan hasil yang ditunjukkan oleh Gambar 1 dan Gambar 2. Kuesioner memiliki 4 jawaban. Jawaban dibagi menjadi empat skala yaitu sangat penting, penting, tidak penting dan sangat tidak penting. Adapun aktor dalam perancangan sistem ini ada 3 yaitu:

a. Masyarakat/Pelapor

Masyarakat merupakan aktor utama yang melaporkan setiap kejadian emergency ataupun kejadian non emergency yang menjadi cakupan tugas PMI

b. Admin PMI

Admin PMI merupakan aktor utama dalam merespon laporan seperti menghubungi pelapor secara otomatis, memantau progress tugas driver, menghubungkan dokter jaga jika keadaan sangat darurat.

c. Driver PMI

Driver PMI merupakan aktor lapangan

\subsection{Hasil Kuesioner}

Tim PMI (Admin)

Tim PMI menguji tingkat prioritas backlog pada menunya melalui kuesioner. Hasil pengujian ditunjukkan pada Tabel 5 dan visualisasi diagram pada Gambar 8. Adapun penjelasan tentang tabel adalah sebagai berikut:

1. Metode Pengukuran menggunakan skala likert dengan 4 skala yaitu sangat penting(SP), penting(P), tidak penting(TP), sangat tidak penting(STP).

2. Keterangan F1-F8 merupakan fasilitas system yang disediakan. Ada 8 fasilitas untuk admin, 3 untuk driver dan 4 untuk masyarakat atau pelapor.

3. $\mathrm{P}(\%)$ merupakan prosentase persetujuan positif oleh responden. Prosentase dihasilkan dari penggabungan skala 3 dan 4 yaitu sangat penting dan penting karena dianggap positif. 
Tabel 5 Hasil Kuesioner Produk Backlog Tim PMI

\begin{tabular}{|l|c|c|c|c|c|c|c|c|}
\hline & F 1 & F 2 & F 3 & F4 & F 5 & F 6 & F7 & F 8 \\
\hline SP & 18 & 13 & 9 & 15 & 13 & 11 & 18 & 10 \\
\hline P & 0 & 4 & 5 & 3 & 2 & 5 & 0 & 3 \\
\hline TP & 0 & 0 & 4 & 0 & 3 & 2 & 0 & 2 \\
\hline STP & 0 & 0 & 0 & 0 & 0 & 0 & 0 & 3 \\
\hline $\mathbf{P ( \% )}$ & 100 & 94,44 & 77,77 & 100 & 83,33 & 88,88 & 100 & 72,22 \\
\hline
\end{tabular}

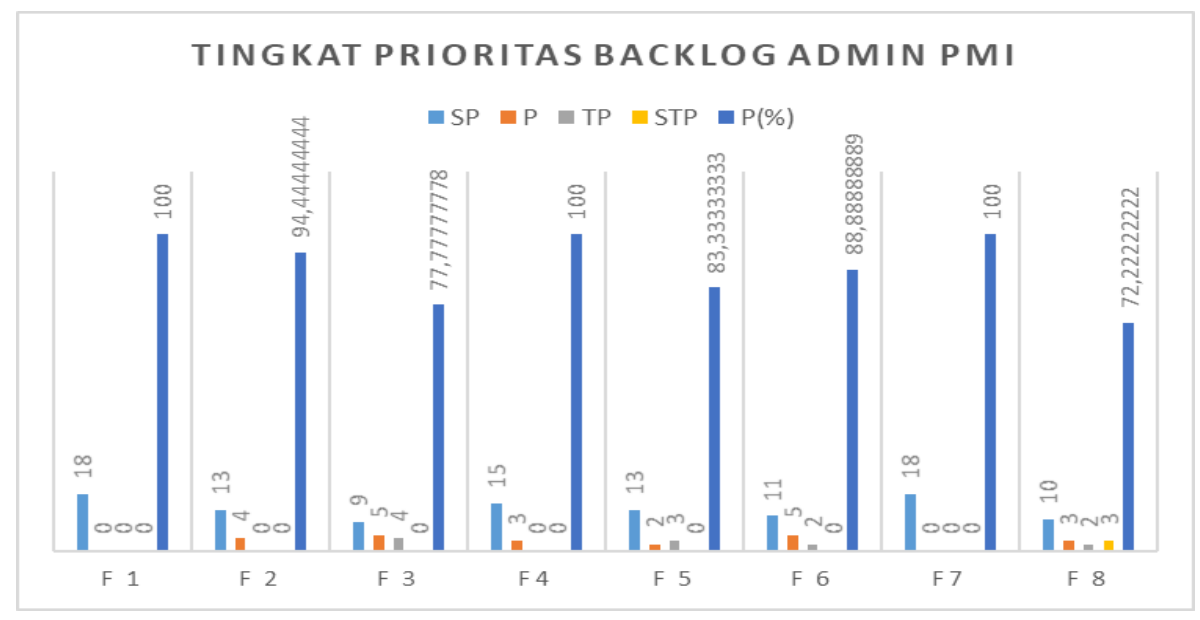

Gambar 8. Visualisasi Tingkat Prioritas Produk Backlog Admin PMI

Tingkat prioritas backlog dibagi menjadi dua kelompok yaitu penting dan tidak penting. Prioritas penting merupakan gabungan dari skala sangat penting dan penting sedangkan tidak penting merupakan gabungan dari skala tidak penting dan sangat tidak penting. Pada kuesioner hasil backlog fasilitas 1, 4 dan 7 memiliki prioritas tertinggi yaitu $100 \%$ diikuti fasilitas 2,6,5 dan fasilitas 3,8 memiliki fasilitas sedang karena prosentase hanya sekitar $70 \%$.

Adapun hasil kuesioner untuk driver digambarkan pada Gambar 9 dan Tabel 6.

Tabel 6 Hasil Kuesioner Produk Backlog Driver

\begin{tabular}{|l|c|c|c|}
\hline & F 1 & F 2 & F 3 \\
\hline SP & 7 & 4 & 3 \\
\hline P & 0 & 2 & 2 \\
\hline TP & 0 & 1 & 2 \\
\hline STP & 0 & 0 & 0 \\
\hline $\mathbf{P ( \% )}$ & 100 & 85,71 & 71,42 \\
\hline
\end{tabular}




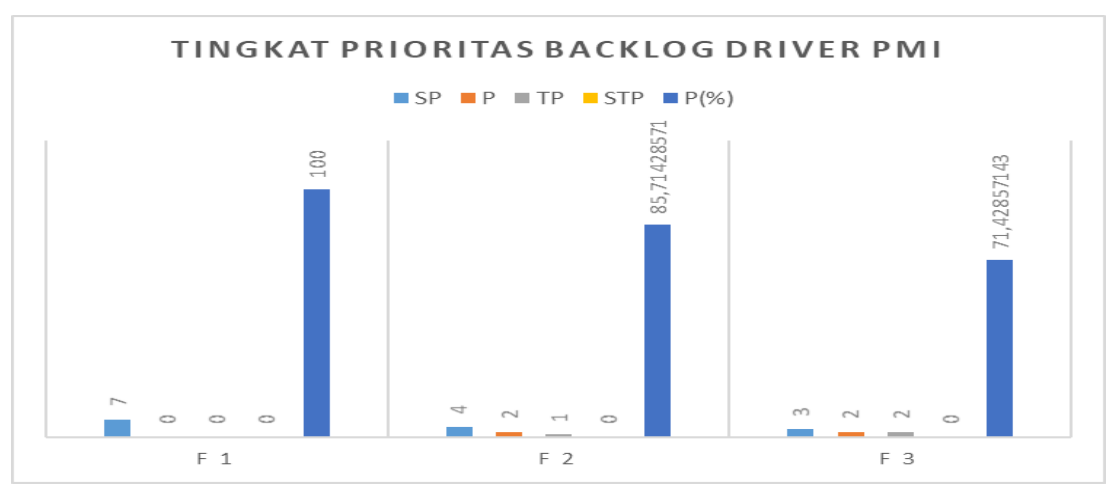

Gambar 9 Tingkat Prioritas Produk Backlog Driver

Tingkat prioritas pada driver, backlog fasilitas 1 prioritas tertinggi yaitu $100 \%$ diikuti fasilitas 2. fasilitas 3 memiliki fasilitas paling rendah hanya sekitar $70 \%$.

Tabel 7 Hasil Kuesioner Produk Backlog Masyarakat/Pelapor

\begin{tabular}{|l|c|c|c|c|}
\hline & F 1 & F 2 & F 3 & F4 \\
\hline SP & 19 & 15 & 13 & 3 \\
\hline P & 6 & 7 & 10 & 8 \\
\hline TP & 0 & 3 & 2 & 11 \\
\hline STP & 0 & 0 & 0 & 3 \\
\hline P(\%) & 100 & 88 & 92 & 44 \\
\hline
\end{tabular}

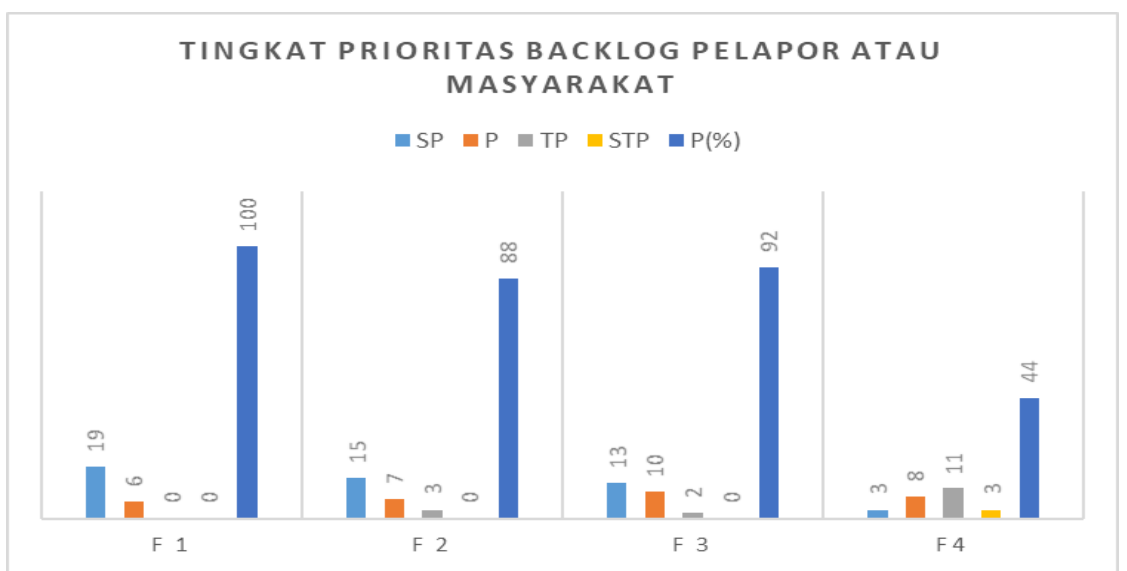

Gambar 10 Tingkat Prioritas Produk Backlog Masyarakat atauPelapor

Tingkat prioritas pada masyarakat atau pelapor, backlog fasilitas 1 tertinggi yaitu $100 \%$ diikuti fasilitas 3 dan 2. fasilitas 4 memiliki fasilitas paling rendah hanya sekitar $44 \%$. Fasilitas ini dianggap kurang priorotas dari sisi pelapor atau masyarakat.

\section{Kesimpulan}

Adapun urutan prioritas pada produk backlog admin PMI adalah fasilitas 1,4,7,2,6,5. Adapun fasilitas memiliki prioritas sedang karena prosentasenya sekitar $70 \%$ terdapat pada fasilitas 3 dan 8 . Adapun urutan prioritas produk backlog untuk driver adalah fasilitas 1 dan 2. fasilitas 3 memiliki fasilitas sedang karena prosentase hanya sekitar $70 \%$. Prioritas produk backlog masyarakat atau pelapor terdiri dari fasilitas 1,3 dan 2. Fasilitas 4 menjadi fasilitas 
paling rendah prioritasnya karena prosentasenya hanya 44\%. Fasilitas 4 pada pelapor atau masyarakat mendapat respon yang rendah dari stakeholder masyarakat. Adapun pengembangan yang harus dilakukan untuk perancangan produk backlog sistem emergency button PMI adalah dari sisi kerjasama dengan rumah sakit rujukan secara tersistem.

\section{UCAPAN TERIMA KASIH}

Ucapan terima kasih kepada pihak Institut Teknologi dan Bisnis Asia Malang sebagai perguruan tinggi penulis. Ucapan terima kasih secara khusus untuk DPRM RISTEKDIKTI yang telah memberikan dana hibah PKM Tahun 2019 untuk pelaksanaan Tahun 2020. Dana digunakan untuk menunjang penelitian ini.

\section{Daftar Pustaka}

[1] Badan Pusat Statistik, "Jumlah Kecelakaan, Koban Mati, Luka Berat, Luka Ringan, dan Kerugian Materi yang Diderita Tahun 1992-2017,” $2017 .$.

[2] Palang Merah Indonesia, "Anggaran Dasar dan Anggaran Rumah Tangga Palang Merah Indonesia," Jakarta, 2014.

[3] M. Hamka and U. M. Purwokerto, "Implementasi Framework SCRUM dalam Pengembangan Sistem Informasi Jabatan Fungsional Akademik," in Seminar Nasional Hasil Penelitian dan Pengabdian Pada Masyarakat III Tahun 2017 Pengembangan Sumberdaya menuju Masyarakat Madani Berkearifan Lokal, 2018, no. December 2017, pp. 1-7.

[4] A. S. Perbangsa, M. Hariawan, and B. Pardamean, "Legislation Information System," Proc. 2018 Int. Conf. Inf. Manag. Technol. ICIMTech 2018, no. September, pp. 477-482, 2018, doi: 10.1109/ICIMTech.2018.8528176.

[5] T. Wijaya, "Penerapan Metode Scrum Dan Virtual Private Network Dalam Perancangan Sistem Ordersales," Creat. Commun. Innov. Technol. (CCIT Journal), vol. 11, no. 1, pp. 115-125, 2018.

[6] B. L. Romano and A. D. Da Silva, "Project management using the scrum agile method: A case study within a small enterprise," Proc. - 12th Int. Conf. Inf. Technol. New Gener. ITNG 2015, pp. 774-776, 2015, doi: 10.1109/ITNG.2015.139.

[7] M. Mahalakshmi and M. Sundararajan, "Tracking the student's performance in Webbased education using Scrum methodology," Proc. Int. Conf. Comput. Commun. Technol. ICCCT 2015, pp. 379-382, 2015, doi: 10.1109/ICCCT2.2015.7292779.

[8] B. V. de Carvalho and C. H. P. Mello, "Scrum agile product development method literature review, analysis and classification," Prod. Manag. Dev., vol. 9, no. 1, pp. 3949, 2011, doi: 10.4322/pmd.2011.005.

[9] E. S. F. Cardozo, J. B. F. Araújo Neto, A. Barza, A. C. C. França, and F. Q. B. da Silva, "SCRUM and Productivity in Software Projects: A Systematic Literature Review," pp. 14, 2010, doi: 10.14236/ewic/ease2010.16.

[10] A. Mundra, S. Misra, and C. A. Dhawale, "Practical scrum-scrum team: Way to produce successful and quality software," Proc. 2013 13th Int. Conf. Comput. Sci. Its Appl. ICCSA 2013, pp. 119-123, 2013, doi: 10.1109/ICCSA.2013.25.

[11] D. Rover, C. Ullerich, R. Scheel, J. Wegter, and C. Whipple, "Advantages of agile methodologies for software and product development in a capstone design project," Proc. - Front. Educ. Conf. FIE, vol. 2015-February, no. February, 2015, doi: 10.1109/FIE.2014.7044380. 
[12] V. T. dkk Faniran, "Adopting Scrum as an Agile Approach in Distributed Software Development: A Review of Literature," in 2017 1st International Conference on Next Generation Computing Applications (NextComp) : 19th-21st July 2017, 2017.

[13] Sugiyono, Metode Penelitian Kuantitatif Kualitatif dan R\&D. Bandung: Alfabeta, 2008.

[14] R. Hundhausen, Professional Scrum Development with Microsoft ${ }^{\circledR}$ Visual Studio ${ }^{\circledR} 2012$, 1st Ed. Washington: Microsoft Press, 2012.

[15] R. T. Hans, "Work in Progress - The Impact of the Student Scrum Master on Quality and Delivery Time on Students' Projects," Proc. - 5th Int. Conf. Learn. Teach. Comput. Eng. LaTiCE 2017, pp. 87-90, 2017, doi: 10.1109/LaTiCE.2017.22.

[16] Rosa dan Shalahuddin, Rekayasa Perangkat Lunak Terstruktur dan Berorientasi Objek. Bandung: Informatika Bandung, 2015.

\section{(c) (i) (2)}

SA Digital Zone: Jurnal Teknologi Informasi dan Komunikasi is licensed under a Creative Commons Attribution International (CC BY-SA 4.0) 